\title{
Does Women's Participation in Politics Matter for Economic Development in OIC-15? An Islamic Perspective
}

\author{
Sari Ramdayani ${ }^{1}$, M. Shabri Abd. Majid ${ }^{2 *}$, Suriani ${ }^{3}$ \\ 1, 2, 3Universitas Syiah Kuala, Indonesia \\ E-mail: ${ }^{1}$ Sariramdayani23@gmail.com, ${ }^{2}$ mshabri@unsyiah.ac.id, ${ }^{3}$ suriani@unsyiah.ac.id
}

") Corresponding author

JEL Classification:

$\mathrm{C} 33$

F16

$\mathrm{J} 16$

O11

$\mathrm{P} 48$

Received: March 27, 2021

Revised: April 05, 2021

Accepted: May 07, 2021

\begin{abstract}
This study aims to empirically determine and analyze the role of women's participation in politics, female population growth, trade balance, and women's labor force participation in promoting economic development across 15 OIC countries during the 2006-2017 period, both in short-and long-run from an Islamic perspective. Using the Panel Autoregressive Distributed Lag (ARDL) method, this study found that, in the short term, trade balance and women's labor force participation have promoted Islamic economic development. In contrast, women's participation has a negative effect on the economic development of OIC countries. In the long term, on the other hand, all variables have promoted Islamic economic development in OIC countries, except for the trade balance variable. These findings suggest that coordination and synergy for strengthening economic development among OIC countries need to be enhanced, focusing on women's role in politics, labor force, quality of population, and economic dimensions.
\end{abstract}

\section{Keywords:}

female participation in politics, trade balance, Islamic human development index, women and OIC economies.

\section{How to Cite:}

Ramdayani, S., Majid, M. S. A., \& Suriani, S. (2021). Does Women's Participation in Politics Matter for Economic Development in OIC-15? An Islamic Perspective. Signifikan: Jurnal Ilmu Ekonomi, 10(2), 209-222. https://doi. org/10.15408/sjie.v10i2.20214. 


\section{Introduction}

Economic development is one of the widely discussed issues in various parts of the world, both in developed, underdeveloped and developing countries. Although economic development issues are discussed in different ways and contexts, their objectives are the same: to achieve a better economic development condition that provides prosperity for society. In supporting economic development success, participation from all levels of society is indispensable, although the government is the most responsible institution to realize economic development. As a result, rapid economic development would be easily realized if it involves the community in the development process. The community's presence in every stage of development certainly presents a sense of belonging to the facilities and infrastructure to be built. Consequently, it fosters a sense of responsibility and results in a sustainable economic development process (Hasanah \& Musyafak, 2017).

Economic development objectives are often defined as a continuous process of increasing real income per capita through economic resources and increasing productivity. However, measuring economic development using the increase in per capita income is considered unable to measure the overall improvement of human welfare because it focuses only on economic aspects and ignores other aspects of economic development. In 1990, the United Nations Development Programme (UNDP) introduced the Human Development Index (HDI) as an indicator of economic development that portrays human development in a measurable and representative manner (Rochmawati, 2018). HDI is used to measure the degree of human development, covering aspects of education, health, and the economy (Fadilah, 2019).

Measurement of economic development with HDI that has been considered able to measure the population's welfare, in fact, still reaped many criticisms. The criticism tends to think that the entire population is treated with the same treatment by the government. However, the reality is not so. Thus the concept of HDI offered by the UNDP to measure the level of human development cannot measure human development as a whole from an Islamic perspective. The direction of the theory and the underlying concept of HDI are not based on Maqashid Shari'ah. Therefore, it would be more appropriate for a Muslim-majority country if economic development is measured using the Islamic Human Development Index (I-HDI) (Anto, 2011). In Islam, economic development has a more comprehensive goal. Economic development focuses not only on improving welfare in the world alone, but it also emphasizes developing a more lasting life, namely the Hereafter life. Therefore, economic development should be referred to and based on the provisions justified in Shari'ah (Fadlan, 2010).

The success of economic development is inseparable from the participation of the community. The concept of development, in principle, must also provide justice and prosperity to all communities, both men and women. The involvement of women today has shown significant progress. Women have played various roles and engaged in many strategic positions in people's lives. The diversity of their roles shows that women are a potential resource if their quality is improved and given the same opportunities as men 
to participate in various aspects, both in family life, society, nation, and state. Today, in the life of a nation and a country, many women plunge into the world of politics. This condition is demonstrated by the increasing number of women involved in political parties and even state officials. However, the representation of women in politics is still relatively low. According to World Development Indicators (2019), the number of women occupying parliaments worldwide has only reached $24.6 \%$. Therefore, women's participation in politics still needs to be improved (World Bank, 2020).

Since the Beijing Action Platform was adopted in 1995, the average global female participation in national politics has gradually increased from $11.3 \%$ to nearly $23.8 \%$ in 2018, with 9,275 female Members of Parliaments (MPs) worldwide. As of June 1, 2018, 2,102 female MPs, or $19.2 \%$ of the world's total politician population, were in OIC member countries. Meanwhile, only 29.8\% of female MPs were recorded in developed countries, and $23.9 \%$ of female MPs were from non-OIC countries. This condition indicates that the number of female politicians in the OIC countries is still far from the Beijing Platform's target, 30\%. However, if we look at the developments and trends, it is estimated that OIC countries will reach the target of an average of $30 \%$ of female politicians in parliament by 2040. However, to achieve this target, the government must eliminate cultural, social, and other factors that hinder women's political participation (OIC, 2018).

Besides, the process of economic development is also inseparable from several other macroeconomic factors, such as the growth of the female population, trade balance, and the female workforce's participation. Cabeza-Garc et al. (2018) show that those women's high birth rates negatively affected economic growth. However, when women have greater access to secondary education and the labor market is equal to men, the effect is positive. In addition to the female population's growth, the trade balance is also documented as an economic factor that affects economic growth. In his research, $\mathrm{Xu}$ (2015) found that the trade balance, as measured by the number of exports and imports, had influenced economic growth. Another economic factor that also contributes to economic development is the participation rate of the female workforce. The female workforce's participation rate in the service industry sector positively affected economic development (Ustabas \& Gulsoy, 2020).

The above-reviewed studies have only measured and analyzed the role of women's participation in politics, women's population growth, trade balance, and women's labor force participation in economic development from a conventional perspective. However, none of them has measured economic development from an Islamic perspective using the Islamic Human Development Index (I-HDI). Thus, previous researches that used HDI as an indicator of economic development have not been able to measure economic development in the OIC countries in the context of Maqashid Shari'ah. This fact prompted this research to be conducted, primarily to empirically measure and analyze the determinants of economic development of the OIC countries from an Islamic perspective using Islamic HDI (I-HDI). In addition, the present study includes the role of women in politics in the economic development of the OIC countries, one of the determinants of economic development that is often ignored by many previous studies. 
Thus, this study intends to cover the weaknesses of previous researches, aiming at measuring and analyzing the role of women's participation in politics on economic development empirically. It also measures and explores the influence of several other economic factors, including the growth of the female population, trade balance, and the female workforce's participation rate on the economic development of the OIC countries from an Islamic perspective using I-HDI as the indicator for economic development.

This study's findings are hoped to shed some light on the OIC governments to design a proper policy to enhance women's roles in politics and other macroeconomic determinants to promote their economic development. The study's findings expect to provide policy references and guidelines for the macroeconomic policy harmonization among OIC countries to realize sustainable economic development.

\section{Methods}

This study quantitatively measures the impacts of Female Participation in Politics (FPP), Female Population Growth (FPG), Trade Balance (TB), and Female Participation in Labor Force (FPLF) on the Islamic Human Development Index (I-HDI) among selected organizations of Islamic Cooperation (OIC) countries over the period 2006-2017. The reason for choosing the independent variables is their ability to describe Islamic human development from various contexts, such as political factors represented by female participation in politics, demographic factors represented by female population growth, and economic factors characterized by the trade balance and female participation in the labor force. Due to data limitations of 57 OIC countries, this study only focuses its analysis on 15 OIC countries, namely Albania, Azerbaijan, Bahrain, Bangladesh, Cote d'Ivoire, Gabon, Guyana, Iran, Jordan, Kazakhstan, Kuwait, Libya, Malaysia, Oman, and Senegal.

The data used in this study are annual data for the period 2006-2017. All data in this study are gathered from the Economic and Social Research data in the OIC Statistics Database report released on the official website of the Statistical Economic and Social Research and Training Center for Islamic Countries (SESRIC). The dependent variable, I-HDI, is calculated based on Maqashid Shari'ah components, following the study by Anto (2011). The numbers of seats held by women in national parliaments measure the independent variables of female participation in politics. The female population growth is using the growth of females to the total population growth. The trade balance is measured by the ratio of exports and imports of goods and services to total GDP. Finally, female participation in the labor force is measured by the percentage of the female labor force (15-64 years old) to total employment, following the study by $\mathrm{Xu}$ (2015).

This study adopts an Autoregressive Distributed Lag (ARDL) panel regression analysis method to measure I-HDI determinants among selected OIC countries. In general, the ARDL equation can be written as follows: 


$$
\begin{aligned}
\Delta I H D I_{i t}= & \varphi_{i}\left(\alpha, \beta_{1}^{\prime} I H D I_{i t-1}-\alpha, \beta_{2}^{\prime} F P P_{i t}-\alpha, \beta_{3}^{\prime} F P G_{i t}-\alpha, \beta_{4}^{\prime} T B_{i t}-\alpha, \beta_{5}^{\prime} F P L F_{i t}\right)+ \\
& \sum_{j=1} p \alpha_{i j}^{*} \Delta I H D I_{i, t-j}+\sum_{j=0} p \delta_{i j}^{*} \Delta \mathrm{FPP}_{i, t-j}-\Delta F P G_{i, t-j}-\Delta T B_{i, t-j}- \\
& \Delta \mathrm{FPLF}_{i, t-j}+\mu_{i}+\varepsilon_{i t}
\end{aligned}
$$

Where: IHDI is an Islamic Human Development Index; FPP is the female participation in politics; FPG is the female population growth; TB is the trade balance; FPLF is the female participation in the labor force; $\mathrm{i}$ is the country $\mathrm{i}$; $\mathrm{t}$ is the period $\mathrm{t}$; $\Delta$ is the change or the first difference, $\mathrm{a}$ is a short-term estimated coefficient; $\mathrm{r}$ is a long-term estimated coefficient; $\mathrm{m}$ is an error correction term; e is an error term.

Before the ARDL model is estimated, the study performs first the data stationarity tests, followed by the co-integration test. These tests are essential to ensure that the ARDL model estimation requirements are met. For stationarity tests, the method used is the standard unit root tests of Levin, Lin, and Chu (LLC) and individual unit root tests of Augmented Dickey-Fuller (ADF) Fisher and Phillips-Peron (PP) Fisher. As for the ARDL panel data co-integration test, the study utilizes the Pedroni Residual Cointegration test.

\section{Result and Discussion}

\section{Descriptive statistics}

Table 1 illustrates the descriptive analysis for investigated variables, namely: Islamic Human Development Index (I-HDI), Female Participation in Politics (FPP), Female Population Growth (FPG), Trade Balance (TB), and Female Participation in Labor Force (FPLF) over the period 2006-2017.

Table 1. Descriptive Statistics

\begin{tabular}{ccccc}
\hline Variable & Minimum & Maximum & Mean & Std. Deviation \\
\hline I-HDI & 0.19 & 0.63 & 0.35 & 0.09 \\
FPP & 1.54 & 43.33 & 13.02 & 9.43 \\
FPG & 0.41 & 1.07 & 0.92 & 0.15 \\
TB & 12.47 & 235.54 & 93.30 & 34.02 \\
FPLF & 13.27 & 77.45 & 42.54 & 15.71 \\
\hline
\end{tabular}

Source: Data processed (2021).

Table 1 shows that the minimum value of I-HDI that represents the Islamic economic development is recorded for Libya by $0.19 \%$ in 2011 . This condition because the fall of Gaddafi's government was, for the first time, an opportunity for the Libyan state to determine the economic and social reforms it had previously prevented. The maximum value of I-HDI was recorded for the Islamic Republic of Iran by $0.63 \%$ in 2017. Based on data from Iran's economic outlook, in 2017, the country recorded a solid oil-based recovery, with an annual growth rate of $13.4 \%$, compared to a contraction of $1.3 \%$ in 2015 . The most considerable growth contribution came from the industrial 
sector (about 25\%); oil and gas production increased by 62\%, mainly due to the lifting of international sanctions (Ustabas \& Gulsoy, 2020).

As for the variable of female participation in politics, the lowest participation was found in Kuwait by only $1.54 \%$ in 2006-2008. Women in Kuwait were only given the right to vote and run for parliamentary and city elections in 2006. The female candidates cannot win seats in the eleventh and twelfth assemblies. Meanwhile, the maximum value of female participation in politics in Senegal is $43.33 \%$ in 2014. Senegal has received international recognition for its efforts towards women's political participation by adopting the Gender Parity Law (2010). As a result of this law that demands parity in the electoral list, the proportion of seats held by women in the national parliament has increased significantly.

Next, the lowest value for female population growth in Oman is $0.41 \%$ in 2008. The fertility rate in Oman has decreased from 8.6 births per woman in 1988 to 3.3 births per woman in 2008. This fact shows a decrease of 5.3 births per woman or a $62 \%$ reduction in a short 20-year period. Fertility has decreased mainly due to synchronized delay and spacing of births among the younger cohort of women and the tradition of prolonged postpartum in fecundability (Islam, 2017). Meanwhile, the maximum female population growth value in Kazakhstan is $1.07 \%$ in 2006. Kazakhstan ranked high overall for gender and development indicators. Over the year, based on the Gender Development Index (GDI), the percentage of women was 0.795 higher compared to 0.790 for men. Overall, it showed high equality between women and men. Kazakhstan continues to reduce its Gender Inequality Index (GII) from 0.405 in 2000 to 0.202 in 2015, lower than the 0.279 averages for European and Central Asian countries (ADB, 2018).

As for the trade balance, Malaysia recorded the lowest values, which amounted to $12.47 \%$ in 2007. Based on the Malaysian Economic Outlook 2007 data, Malaysia's economic growth was strong in 2007, driven by strong consumption and increased investment activity. However, compared to other OIC countries, Malaysia was the lowest despite the trade balance's good performance (Bank Negara Malaysia, 2007). Meanwhile, the maximum value of the trade balance was recorded for Libya by $235.54 \%$ in 2014 . This condition happened because the Libyan economy experienced strong growth despite the severe drought in 2007. Extensive investment and high consumption resulted in a 6\% growth in real terms in 2007, the highest since 2002 (Commission Staff Working Document, 2008).

Finally, the minimum female labor force participation rate was recorded for Jordan by $13.27 \%$ in 2006. Labor market inclusion for Jordanian women is among the lowest in the world. The national unemployment estimate for Jordanian women reached $26.9 \%$ in 2018. Based on the World Bank report in 2018, this is the 5th highest female unemployment rate among 188 countries globally. Not only that, but the female labor force participation rate in Jordan (15.0\%) is also the 4th lowest in the world.

On the other hand, the maximum female labor force participation rate was Albania at $77.45 \%$ in 2008 . This condition is because many Albanian women are involved in the business, so that women entrepreneurs spend most of their time working, more 
than 10 hours a day. Acquiring knowledge and education, showing perseverance, and confidence in the business world are considered the main reasons for success in their business activities (Ramadani, 2015).

\section{Stationarity test results}

The study performs the stationarity test to ensure the model estimation's data suitability before ARDL estimation. For this purpose, the standard unit root statistical tests of LLC and individual unit root of ADF-Fisher and PP-Fisher are used.

Table 2 illustrates that the results of stationarity tests using LLC, ADF-Fisher, and PP-Fisher both for models without trends and with trend contain unit root at the I-HDI level. I-HDI becomes stationarity at the first difference, I (1). Meanwhile, all dependent variables have no unit root, or the data is stationary at level $\mathrm{I}(0)$. Thus, this confirms the suitability of using the ARDL method to determine the effect of female participation in politics, female population growth, trade balance, and female participation in the labor force on economic development between OIC-15. The ARDL model requires the dependent variable to be stationary at first different, I(1), while other independent variables can be stationary at different levels, I(0) or I(1).

Table 2. Stationarity Test Results

\begin{tabular}{|c|c|c|c|c|c|c|}
\hline \multirow{3}{*}{ Variables } & \multicolumn{5}{|c|}{ Without Trend } & \\
\hline & \multicolumn{3}{|c|}{ Level } & \multicolumn{3}{|c|}{$1^{\text {st }}$ Difference } \\
\hline & LLC & ADF & PP & LLC & ADF & PP \\
\hline I-HDI & $\begin{array}{l}0.0643 \\
0.5256\end{array}$ & $\begin{array}{l}12.1990 \\
0.9984\end{array}$ & $\begin{array}{l}29.1525 \\
0.5096\end{array}$ & $\begin{array}{c}-3.5561 \\
0.0002^{* * *}\end{array}$ & $\begin{array}{l}42.1450 \\
0.0696^{*}\end{array}$ & $\begin{array}{c}111.432 \\
0.0000^{* * *}\end{array}$ \\
\hline FPP & $\begin{array}{c}-4.0098 \\
0.0000^{* * *}\end{array}$ & $\begin{array}{c}38.3312 \\
0.1414\end{array}$ & $\begin{array}{l}42.3745 \\
0.0665^{*}\end{array}$ & $\begin{array}{c}-8.3686 \\
0.0000^{* * *}\end{array}$ & $\begin{array}{c}75.2747 \\
0.0000^{* * *}\end{array}$ & $\begin{array}{c}130.726 \\
0.0000^{* * *}\end{array}$ \\
\hline FPG & $\begin{array}{l}-1.6568 \\
0.0488^{* *}\end{array}$ & $\begin{array}{c}36.8039 \\
0.1829\end{array}$ & $\begin{array}{l}38.1891 \\
0.1450\end{array}$ & $\begin{array}{l}-1.7116 \\
0.0435^{* *}\end{array}$ & $\begin{array}{l}50.3609 \\
0.0011^{* *}\end{array}$ & $\begin{array}{c}91.5893 \\
0.0000^{* * *}\end{array}$ \\
\hline $\mathrm{TB}$ & $\begin{array}{l}-14.8838 \\
0.0000^{* * *}\end{array}$ & $\begin{array}{l}54.0721 \\
0.0045^{* *}\end{array}$ & $\begin{array}{l}39.1200 \\
0.1231\end{array}$ & $\begin{array}{c}-3.9465 \\
0.0000^{* * *}\end{array}$ & $\begin{array}{c}66.4283 \\
0.0001^{* * *}\end{array}$ & $\begin{array}{c}159.731 \\
0.0000^{* * *}\end{array}$ \\
\hline FPLF & $\begin{array}{l}-81.4965 \\
0.0000^{* * *}\end{array}$ & $\begin{array}{c}38.8752 \\
0.1285\end{array}$ & $\begin{array}{l}57.4616 \\
0.0018^{* *}\end{array}$ & $\begin{array}{c}-459.24 \\
0.0000^{* * *}\end{array}$ & $\begin{array}{l}55.9898 \\
0.0027^{* *}\end{array}$ & $\begin{array}{c}85.3195 \\
0.0000^{* * *}\end{array}$ \\
\hline \multicolumn{7}{|c|}{ With Trend } \\
\hline I-HDI & $\begin{array}{c}0.41272 \\
0.6601\end{array}$ & $\begin{array}{c}20.9538 \\
0.8893\end{array}$ & $\begin{array}{c}36.9848 \\
0.1776\end{array}$ & $\begin{array}{l}-2.1198 \\
0.0170^{* *}\end{array}$ & $\begin{array}{c}16.7302 \\
0.9757\end{array}$ & $\begin{array}{c}69.1742 \\
0.0001^{* * *}\end{array}$ \\
\hline FPP & $\begin{array}{c}-7.6555 \\
0.0000^{* * *}\end{array}$ & $\begin{array}{l}49.5564 \\
0.0013^{* *}\end{array}$ & $\begin{array}{l}57.2990 \\
0.0019^{* *}\end{array}$ & $\begin{array}{c}-6.8157 \\
0.0000^{* * *}\end{array}$ & $\begin{array}{l}43.8860 \\
0.0488^{* *}\end{array}$ & $\begin{array}{c}108.659 \\
0.0000^{* * *}\end{array}$ \\
\hline FPG & $\begin{array}{c}-2.0242 \\
0.00215^{* *}\end{array}$ & $\begin{array}{c}22.0476 \\
0.8523\end{array}$ & $\begin{array}{c}17.9175 \\
0.9599\end{array}$ & $\begin{array}{c}-4.6834 \\
0.0000^{* * *}\end{array}$ & $\begin{array}{c}48.0607 \\
0.00196^{* *}\end{array}$ & $\begin{array}{c}123.701 \\
0.0000^{* * *}\end{array}$ \\
\hline $\mathrm{TB}$ & $\begin{array}{c}-9.3066 \\
0.0000^{* * *}\end{array}$ & $\begin{array}{c}38.2675 \\
0.1430\end{array}$ & $\begin{array}{c}36.0791 \\
0.2055\end{array}$ & $\begin{array}{l}-0.4870 \\
0.3132\end{array}$ & $\begin{array}{c}38.0301 \\
0.1490\end{array}$ & $\begin{array}{c}147.382 \\
0.0000^{* * *}\end{array}$ \\
\hline FPLF & $\begin{array}{l}-342.472 \\
0.0000^{* * *}\end{array}$ & $\begin{array}{l}45.7295 \\
0.0330^{* *}\end{array}$ & $\begin{array}{l}39.0739 \\
0.1241\end{array}$ & $\begin{array}{l}-446.64 \\
0.0000^{* * *}\end{array}$ & $\begin{array}{c}60.0991 \\
0.0009^{* * *}\end{array}$ & $\begin{array}{c}89.9489 \\
0.0000^{* * *}\end{array}$ \\
\hline
\end{tabular}

Note: Significance level ${ }^{* * *}(1 \%),{ }^{* *}(5 \%)$, and ${ }^{*}(10 \%)$.

Source: Data processed (2021). 


\section{Cointegration test results}

After ensuring the data stationary in the previous stage, the next step is to test the ARDL panel data's co-integration. This step is done to determine whether the observed data share a long-term relationship or co-integration between variables. In the study, the co-integration is tested using the Pedroni Residual Cointegration test. Table 3 reports the findings of co-integration from the Pedroni Residual Cointegration test.

As illustrated in Table 3 using the Pedroni test, the co-integration results show co-integration among the investigated variables at the $1 \%$ level of significance. Since the Pedroni test's probability value is smaller than $1 \%$, and its estimated coefficient is negative, the data is considered cointegrated, or there is a long-term relationship among the variables. In Table 3, the probability values were 0.001 and 0.008 . Their slope is negative, except for the v-statistics panel, the rho-statistics panel, the ADF-statistics panel, the rho-statistics group, and the ADF-statistics group. These results conclude that there is co-integration among the variables of female participation in politics, female population growth, trade balance, women's labor force participation, and Islamic economic development (I-HDI).

Table 3. Cointegration Test on Pedroni Test

\begin{tabular}{lcccc}
\hline & Statistic & Prob. & Weighted Statistic & Prob. \\
\hline Panel v-Statistic & -4003.16 & 1.000 & -1.563 & 0.941 \\
Panel rho-Statistic & 1.265 & 0.897 & 1.415 & 0.921 \\
Panel PP-Statistic & $-2.442^{* * *}$ & 0.007 & -3.761 & 0.001 \\
Panel ADF-Statistic & $0.805^{*}$ & 0.789 & -1.287 & 0.099 \\
Between Dimension & & & & \\
\hline & Statistic & Prob. & & \\
\hline Group rho-Statistic & 2.771 & 0.997 & & \\
Group PP-Statistic & $-3.172^{* * *}$ & 0.008 & & \\
Group ADF-Statistic & -3.432 & 0.366 & & \\
\hline
\end{tabular}

Note: Significance level ${ }^{* * *}(1 \%)$ and ${ }^{*}(10 \%)$.

Source: Data processed (2021).

\section{The Determinant of Islamic Economic Development}

After the stationarity and co-integration tests conduct, the next is to estimate the ARDL panel model. The finding of the ARDL estimation is showing in Table 4. As observed from the table, in the short term, the variable female participation in politics (FPP) is found to not affect economic development from an Islamic perspective (I-HDI). In the short term, female involvement in politics has not been influential due to society's patriarchal cultural practices. However, it does not mean that their presence in politics has no contribution to overall economic development in the long run.

As illustrated in Table 4, in the long term, female participation in politics (FPP) 
has a significant positive effect on Islamic economic development (I-HDI), indicating the importance of female participation in economic development. This finding aligns with research conducted by $\mathrm{Xu}$ (2015), where women's involvement in politics influenced economic growth. One way to improve female participation in politics is by setting a quota of $30 \%$ of seats in the national parliament to be occupied by women. The OIC Women and Development Report (2018) predict that female participation in politics will increase in OIC countries in 2040.

From the beginning, Islam also emphasized the importance of acquiring knowledge and education for both men and women. Thus, Muslim countries must take initiatives to increase female participation in education and politics. Women who take part in politics can solve existing women's social-related problems. Educated women can also create a brilliant generation. This result aligns with Bullough et al. (2012), who analyzed women's political leadership participation worldwide using institutional analysis that had contributed to economic development. In line with the study carried out by Faizul et al. (2020), they showed that the educated female politician had been the most potent instrument for the twenty-first century in the twenty-first-century progress and prosperity of a nation. However, to increase the participation of women's political leadership, we need to evaluate matters related to customs and trade regulations, corruption, gender disparities in political empowerment, public spending on education, state economic sustainability, access to power and the internet, political freedom, and cultural aspects, including performance orientation, collectivism, and power distance. Further research carried out by Khorsheed (2019) stated that women make up half of the global population, and consequently, women are half of the creators, talent creators, and potential innovators. The study found a significant positive effect of women Members of Parliaments (MPs) on economic growth, showing women's crucial roles in politics to stimulate economic growth.

Table 4. ARDL Panel Data Estimation Results in Short and Long Term

\begin{tabular}{ccccc}
\hline Variable & Coefficient & Std. Error & t-Statistic & Prob* $^{*}$ \\
\hline ECT(-1) & -0.5712 & Short Run Equation & \\
D(FPP) & 0.0097 & 0.1482 & -3.8553 & 0.0002 \\
D(FPG) & -2.3838 & 0.0085 & 1.1498 & 0.2535 \\
D(TB) & 0.0004 & 1.2265 & -1.9436 & $0.0553^{*}$ \\
D(FPLF) & 0.2690 & 0.0005 & 0.7233 & 0.4715 \\
\hline FPP & 0.2364 & 1.1382 & 0.2583 \\
\hline FPG & 0.0046 & Long Run Equation & & $0.0000^{* * *}$ \\
TB & 3.4464 & 0.0007 & 6.5476 & $0.0000^{* * *}$ \\
FPLF & 0.0002 & 0.7891 & 4.3678 & 0.4546 \\
\hline
\end{tabular}

Note: Significance level ${ }^{* * *}(1 \%),{ }^{* *}(5 \%)$ and ${ }^{*}(10 \%)$.

Source: Data processed (2021). 
Regarding female population growth (FPG), the study found it to have a significant adverse effect on Islamic economic development (I-HDI) in the short run. This result shows that, in the short run, an increase in the female population had caused a decrease in Islamic economic development. This condition occurs because women's empowerment has not achieved economic development goals in the short run, although almost half of the population in OIC countries is women. This condition is simply due to the high level of gender disparities in OIC countries. Meanwhile, in the long term, the female population growth has a significant positive effect on economic development from an Islamic perspective (I-HDI). In the long run, an increase in the female population has led to increased Islamic economic development. A long-term policy that focuses on improving the quality of education for women, the level of good health for women, and equal opportunities for making decisions in public has empowered women's contribution to economic development (COMCEC, 2017).

Next, as illustrated in Table 4, the study found an insignificant effect of Trade Balance (TB) on economic development from an Islamic perspective (I-HDI) both in the short- and long run. The following phenomenon explains the insignificance of the trade balance to OIC's economic development. Based on the 2017 OIC Economic Outlook Report, the process of industrial development in OIC countries has been slow to develop over the last few decades. The OIC countries' share in total world manufacturing value added increased from $4.9 \%$ in 1990 to only $7.7 \%$ in 2016 . There was also strong growth in the trade deficit in manufactured products, reflecting the insufficient manufacturing production capacity in OIC countries. Based on this report, OIC countries need to refocus their attention on economic diversification or expansion in the manufacturing sector to narrow the economic development gap and increase economic diversification. A well-diversified economy requires a solid and sophisticated manufacturing industry to improve and maintain its competitiveness in the global economy. In this regard, it is vital to understand the problems behind previous industrialization efforts' successes and failures in designing industrial policies. It is also essential to create synergies between member countries' trade and investment policies, with particular attention paid to measures that stimulate product value chains in industrial development (OIC, 2017).

Regarding female participation in the labor force (FPLF), the study also found no significant effect of the variable on economic development from an Islamic perspective (I-HDI) in the short run. Most women who work in the labor market accept low-quality jobs, causing their participation in the labor force to have no significant impact on economic development in the short run. It is also closely related to gender inequalities in the labor market. Women are more likely to be underestimated in making a policy, coupled with women's nature considered weak and their marginalized position within society. The OIC Women and Development Report (2018) showed that most women in OIC countries work primarily in the service sector (45\%) and agriculture (41\%).

Meanwhile, to increase economic development in developed countries, women tend to be more employed in the service sector (88\%) and industry (15\%) (OIC, 2018). However, in the long term, female participation in the labor force has a significant 
economic development effect from an Islamic perspective (I-HDI). This condition means that an increase in female participation in the labor force had led to a rise in Islamic economic development among 15 OIC countries in the long run by an estimated coefficient of 0.0294 . Women are an essential factor in increasing economic development.

The involvement of women in the economic sector is needed to achieve prosperity in society. OIC country governments' strategies are to create a long-term-based program called the OIC-2025 Program of Action (OIC, 2018). In this program, governments in OIC countries recognize the importance of the labor market to build a better quality of life, promote productive employment, and create adequate social protection for the OIC community. These could be done by increasing labor competitiveness, creating a harmonious and progressive workplace, and promoting decent work for everyone (OIC, 2017). In essence, women's participation in the workforce will ultimately improve their economic situation and contribute to economic efficiency by enhancing the country's potential (Mujahid \& Zafar, 2012). Our finding aligns with Fatima \& Sultana (2009), who documented that female labor force participation has a positive and robust relationship to economic growth.

However, it is essential to note that Islamic economics has a much comprehensive mission than its conventional counterpart. Islamic economic development is not simply building the people's economy, but it is, more importantly, promoting a mental attitude, which also means developing a whole human being. It is not only developing the physical side but also empowering transcendental spiritual needs. In Islam, economic development refers to alleviating poverty and providing ease, comfort, and decency in life. It is the process of reducing poverty and creating peace, comfort, and moral order in life. In this sense, economic development from an Islam perspective covers multidimensional aspects, both quantitative and qualitative. Its goal is not solely material welfare in the world but also the interest of the Hereafter. Both of them are integral and mutually interdependent. Islam sees economic development as the growth of human maturity, where material progress must support spiritual maturity. According to Almizan (2016), several important goals must be prioritized: growth accompanied by full-employment, economic stability, distributive justice, and care for nature. Regarding population control, it is inseparable from the Shari'ah norms, highlighted in the Maqahasid Shari'ah.

Furthermore, Islam sees Allah created both men and women to the same degree. There is no indication that the first woman (Eve) whom Allah created was a creature with a lower dignity than the first man (Adam). Allah Almighty said in the Holy Qur'an:

"O people, fear your Lord who created you of the same type and from him, Allah has created a mate and in both Allah breeds a multitude of men and women" (An-Nisa, Verse 1).

This verse affirmed that the materials for man's creation are not different from women, and they created the same type. Islam does not recognize discrimination between men and women. Islam places women as equal partners to men. Even if there are differences, it results from the main functions and duties assigned by religion to each 
gender so that the differences do not result in one feeling that he has an advantage over the other. Both are complementary and help each other carry out their functions in their lives (Hadi, 2017).

Islam provides opportunities for women to participate in political activities, as highlighted in many verses in the Qur'an that command amar al- ma'ruf wa nahi almunkar. This condition applies to all kinds of activities, including politics and state affairs, where women are also responsible. Thus, women in Islam also have the right to be involved in politics, such as becoming members of representative institutions and leading formal institutions, organizations, parties, and the president. Of course, generally, women's political participation is subject to human rights in Islam. These human rights are owned without distinguishing the basis of nation, race, religion, gender (Warjiyati, 2016) and contradicting women's Islamic nature. In Islam, women can actively participate in various activities or work in multiple fields inside or outside their homes independently. They can work with other people or government or private institutions, as long as it is performed respectfully and politely. At the same time, they have to observe their religious duties and avoid the negative impacts of the work on themselves and the environment. In short, women have the right to work as long as needed or that position requires them. Most importantly, they should not forget their nature and Islamic injunctions while at work.

Finally, our estimated ARDL model's overall results illustrated in Table 4 are free from model misspecification. The estimated adjusted R2 of 0.6099 is significant at the $1 \%$ level, showing the ability of investigated determinants to predict variations in Islamic human development by $60.99 \%$. This finding indicates that the estimated model used is quite good at explaining the economic development determinants of 15 OIC countries from an Islamic perspective. The Islamic economic development (I-HDI) is explained mainly by the political factor (i.e., female participation in politics), demographic factor (i.e., female population growth), and economic factors (i.e., trade balance and female participation in the labor force).

\section{Conclusion}

This study empirically measured and analyzed the role of women's participation in politics, female population growth, trade balance, and women's labor force participation in promoting Islamic economic development across 15 OIC countries during the 20062017 periods using the panel ARDL model. Combining political, demographical, and economic factors as the determinants of OIC countries' Islamic economic development is the main novelty of this study. The study found that, in the short term, only female population growth significantly and negatively affected Islamic economic development, while other variables did not. Meanwhile, except for the trade balance variable, all variables are documented to influence the economic development of 15 OIC countries from an Islamic perspective in the long term.

These findings show that the orientation of economic development policy designed by the OIC governments should orient to short- and long-run economic development. In 
this case, the OIC countries should strengthen the coordination and synergy to influence the OIC countries. The OIC governments must also continue to strive to provide space for female politicians by imposing a quota of $30 \%$ of women's seats in parliament. With female participation in politics, they are no longer marginalized.

Governments of OIC countries need to refocus their attention on economic diversification or expansion in the manufacturing sector to narrow the economic development gap and increase economic diversification to respond to global economic developments and compete in the world economic arena. Furthermore, the OIC governments must also prioritize gender equality in all activities, increasing women's education, health, and politics. Future studies should incorporate more variables, such as women's education, in measuring economic development from an Islamic perspective. Covering more OIC countries into the analysis would also enrich the empirical findings on this topic.

\section{References}

ADB. (2018). Kazakhstan Country Gender Assessment. Metro Manila, Philippines: Asian Development Bank. https://doi.org/http://dx.doi.org/10.22617/TCS179181.

Almizan. (2016). Economic Development in Islamic Economic Perspective. Maqdis: Journal of Islamic Economic Studies, 1(2), 1-20.

Anto, H. (2011). Introducing an Islamic Human Development Index ( I-HDI ) to Measure Development in OIC Countries. Islamic Economic Studies, 19(2), 69-95.

Bank Negara Malaysia. (2007). The Malaysian Economy in 2007. Retrieved from https:// www.bnm.gov.my/documents/20124/830573/cp01.pdf

Bullough, A., Kroeck, K. G., Newburry, W., Kundu, S. K., \& Lowe, K. B. (2012). Women's Political Leadership Participation Around the World: An Institutional Analysis. The Leadership Quarterly, 23(3), 398-411. https://doi.org/10.1016/ j.leaqua.2011.09.010

Cabeza-garc, L., Brio, E. B. Del, \& Oscanoa-victorio, M. L. (2018). Gender Factors and Inclusive Economic Growth: The Silent Revolution. Sustainability, 10(121), 1-14. https://doi.org/10.3390/su10010121.

COMCEC. (2017). Comcec Trade Outlook. Ankara, Turkey: Commercial Cooperation of the Organization of Islamic Cooperation.

Commission Staf Working Document. (2008). Albania 2008 Progress Report. Brussels: Commission of The European Communities.

Fadilah, K. (2019). Pengaruh Pertumbuhan Ekonomi, Islamic Human Development Index, dan Pengangguran terhadap Kemiskinan: Studi pada Kabupaten/Kota Daerah Istimewa Yogyakarta Tahun 2010-2018. (Unpublished Thesis). Universitas Islam Negeri Syarif Hidayatullah Jakarta.

Fadlan. (2010). Konsep Pembangunan Ekonomi Berbasis Islam: Sebuah Upaya Pembangunan Ekonomi Indonesia yang Adil, Makmur, dan Sejahtera. Al-Ihkam, 5, 257-274.

Faizul, M., Matin, M. A., Nadzrah, A., \& Mohammad, R. (2020). Women's Participation 
in Education and Politics: Evidence from the Selected OIC Countries. Social and Political Sciences, 3(3), 776-788. https://doi.org/10.31014/aior.1991.03.03.210

Fatima, A., \& Sultana, H. (2009). Tracing Out the U-shape Relationship Between Female Labor Force Participation Rate and Economic Development. International Journal of Social Economics, 36, 182-198. https://doi.org/10.1108/03068290910921253

Hadi, A. (2017). Posisi Wanita dalam Sistem Politik Islam Perspektif Fenomelogi. An Nisa'a: Jurnal Kajian Gender Dan Anak, 12(01), 9-20.

Hasanah, U., \& Musyafak, N. (2017). Gender and Politics: Keterlibatan Perempuan dalam Pembangunan Politik. Sawwa: Jurnal Studi Gender, 12, 409-432.

Islam, M. M. (2017). Rapid Fertility Decline in Oman: Understanding the Role of Proximate Determinants. Middle East Fertility Society Journal, 22(4), 275-284. https://doi.org/10.1016/j.mefs.2017.04.007

Khorsheed, E. (2019). Women Parliamentarians Impact on Economic Growth: A Cross-Country Analysis Evidence. Proceeding International Conference on Modeling Simulation and Applied Optimization (ICMSAO) (pp. 1-5). IEEE. https://doi.org/ https://doi.org/10.1109/ICMSAO.2019.8880280

Mujahid, N., \& Zafar, uz N. (2012). Economic Growth-Female Labour Force Participation Nexus: An Empirical Evidence for Pakistan. The Pakistan Development Review, 51(04), 565-585.

OIC. (2017). OIC Economic Outlook. Oran, Ankara- Turkey: OIC.

OIC. (2018). OIC Women and Development Report. Oran, Ankara- Turkey: OIC.

Ramadani, V. (2015). The Woman Entrepreneur in Albania: An Exploratory Study on Motivation Problems and Success Factors. Journal of Balkan and Near Eastern Studies, 17(2), 204-221. https://doi.org/10.1080/19448953.2014.997488

Rochmawati, T. (2018). Analisis Islamic Human Development Index (I-HDI) di Kota Yogyakarta Tahun 2015-2016 dalam Perspektif Maqashid Syariah. (Unpublished Thesis). Universitas Islam Indonesia.

Ustabas, A., \& Gulsoy, T. Y. (2020). The Relationships between the Female Labor Force Participation Rate and Economic Development: A Correlation Analysis for Turkey. Proceeding International Conference on Eurasian Economies, 104-113.

Warjiyati, S. (2016). Partisipasi Politik Perempuan Perspektif Hukum Islam. Al-Daulah, Jurnal Hukum Dan Perundangan Islam, 6(01), 1-27.

World Bank. (2020). World Bank Gender Statistics-Proportion of seats held by women in national parliaments (\%), 2020. Retrieved from https://data.worldbank.org/indicator/ SG.GEN.PARL.ZS

Xu, L. (2015). Effects of Female Political Participation on Economic Growth: Evidence from Asian Countries. (Unpublished Thesis). Lund University. 